\title{
Effect of shear velocity and flow regimes on scallop post-larval detachment feed on two different diets
}

\author{
Renée Gagné ${ }^{a}$, Réjean Tremblay ${ }^{a}{ }^{*}$, Frédéric Olivier $^{\mathrm{a}, \mathrm{b}}$, Fabrice Pernet $^{\mathrm{c}}$, Philippe Miner $^{\mathrm{d}}$, \\ Jean-François Samain ${ }^{d}$
}

\author{
${ }^{a}$ Institut des Sciences de la Mer, Université du Québec à Rimouski, QC, Canada G5L 3A1 \\ b Muséum National d'histoire Naturelle, Département Milieux et Peuplements Aquatiques, UMR BOREA 7208 \\ CNRS/MNHN/P6/IRD, CRESCO, 38, rue du Port Blanc, 35800 Dinard, France \\ ${ }^{c}$ IFREMER, Laboratoire Environnement Ressources, Bd Jean Monnet, 34203 Sète, France \\ d IFREMER DRVIA, Laboratoire de Physiologie des mollusques, Centre de Brest, 29280 Plouzané, France \\ *: Corresponding author : Réjean Tremblay, Tel.: + 14187231986 p1705 ; fax: + 4187241842 ; \\ email address : rejean tremblay@uqar.qc.ca
}

\begin{abstract}
:
Through biological flume experiments, we studied the effect of shear velocity and attachment period on the percent detachment of Pecten maximus post-larvae of different sizes reared on two experimental diets. The first diet, (Pavlova lutheri, Isochrysis galbana, Chaetoceros calcitrans), which served as a reference diet (PTC), is commonly used in bivalve hatcheries; the second is the PTC diet with the addition of Rhodomonas salina (PTCR). Our results indicate that the detachment of postlarvae fed PTCR diet showed significant interactions between scallop length, attachment period and shear stress, while the post-larvae feed with the PTC diet showed only effect of shear stress factor. Furthermore, post-larvae exposed to various flume velocities showed different percentages of detachment according to diet (PTC $=36 \%$ and PTCR $=57 \%$ ) for flow velocities between 1.42 to $2.45 \mathrm{~cm} \mathrm{~s}^{-1}$ after $12 \mathrm{~h}$ attachment periods. This result could be related to differences in the biochemical composition of post-larvae as discussed.
\end{abstract}

\section{Highlights}

Critical shear velocity needed to detach Pecten maximus post-larvae was $1.42 \mathrm{~cm} \mathrm{~s}^{-1}$. Time allowed to settle increase attachment strength. Diet affects the detachment. Higher accumulation of lipids and sterol composition affect attachment strength.

Keywords: Attachment ; Pecten maximus ; Benthic boundary layer ; Flume ; Diet 


\section{Introduction}

The life cycle of most benthic marine invertebrates involves a planktonic phase during which dispersal occurs and a critical phase at the water-substratum interface, within the benthic boundary layer (BBL), where habitat quality is tested prior to settlement and post-larval/juvenile development (Thorson, 1950; Pechenik, 1990; Tremblay et al., 2007a). Settlement of competent larvae is influenced by several factors, including water flow and a variety of biological, chemical and physical cues (Crisp, 1974; Pawlik, 1992; Qian, 1999; Hadfield et al., 2001; Bishop et al., 2006; Larsson and Jonsson, 2006; Mesías-Gansbiller et al., 2008; Pechenik, 2006; Thiyagarajan, 2010; Andersen et al., 2011; Magnesen et al. 2012). The settlement ability of several bivalves is related to the secretion of byssal threads promoting attachment. The Pectinidae foot is small compared to that of Mytilidae; however, it may be more or less developed depending on adult behaviors and the importance of the byssal gland in different species (Mahéo, 1968; Gruffyd et al., 1979). Most scallops begin their post-larval life as byssally attached individuals, but several Pectinid species cease to secrete byssus some months after metamorphosis and start a free-living life on the seabed (Cady, 1972; Minchin, 1992). Prior to settlement, the foot extends from the byssal notch in the shell and explores the surrounding substrates. It then presses against a substrate and several minutes later (410 minutes in Chlamys varia), the foot retracts leaving a filament that fixes the animal to the substrate (Cragg and Crisp, 1991). Pectinid byssus is formed from a base from which 30-50 thick fibrous ribbons extend that are secreted by the primary byssus gland (Gruffyd et al., 1979). Byssal production entails a significant metabolic cost that has been estimated in Mytilus edulis mussels at $8 \%$ of an individual's monthly energy expenditure (Hawkins and Bayne, 1985). In Chlamys islandica scallops, byssus secretion represents 4 to $14 \%$ of the energy budget related to somatic production (Vahl, 1981). Considering this evidence, we hypothesized that attachment ability of post-larvae should be related to the energetic reserves accumulated. However, to our knowledge, no information is available to confirm or reject this hypothesis.

Many factors influence byssus production in scallops. For example, the rate of byssus production increases with temperature (Paul, 1980; Rupp and Parsons, 2004) but decreases with body size (Caddy, 1972; Culver et al., 2006) and with salinity (Christophersen and Strand, 2003; Rupp and Parsons, 2004). Although some field observations indicate that byssal attachment of post-larval and juvenile scallops may be controlled by current velocities, few experimental data are available. Focusing on Argopecten irradians, Eckman (1987) demonstrated that the survival of young recruits was low in areas of high flow, suggesting that byssal attachments to eelgrass blades were broken at high flows.

In this set of experiments, we examined the role of hydrodynamics (shear stress) on the level of detachment of different-sized Pecten maximus scallop post-larvae that had been fed different diets during the larval phase. To our knowledge, our study is the first to test the effects of both diet and hydrodynamic conditions on the attachment capacity of Pecten maximus post-larvae. Our specific goals were (1) to measure the effect of different flow conditions on the detachment of post-larvae, (2) to measure the impact of post-larvae size and attachment duration on detachment level and (3) to assess the potential role of diet on the attachment ability of scallop post-larvae. 


\section{Material and methods}

\subsection{Larval rearing}

Details about the rearing procedure and experimental design are presented in Gagné et al. (2010) showing larval, settlement and post-larval success in relation to two diets. Briefly, in 2006 Pecten maximus larvae were reared in batch system with two nutritional treatments in triplicate $150 \mathrm{I}$ cylindrical-conical tanks at an initial density of 8 larvae $\mu^{-1}$ at $20^{\circ} \mathrm{C}$ in filtered $(1 \mu \mathrm{m})$ seawater treated with UV and mixed with aeration. Bacterial growth was limited by the addition of the antibiotic thiamphenicol at $8 \mathrm{ppm}$ until metamorphosis. The first experimental diet, PTC, was a mix of similar volumes of Pavlova lutheri $(\mathrm{P})$, Isochrysis galbana clone Tahitian $(\mathrm{T})$ and Chaetoceros calcitrans (C); the second, PTCR, was the standard PTC diet plus the microalga Rhodomonas salina (R). PTC is a reference diet commonly used in bivalve hatcheries (Delaunay et al., 1993; Andersen et al., 2011). Larvae were fed daily with 15 cells $\mu^{-1}$ of each algal species as previously described and tested (Tremblay et al., 2007b; Gagné et al., 2010). At the beginning of settlement (27 days post-fertilization), which was verified by the appearance of eyespots and -double-ring" shell edges in more than $50 \%$ of the larvae, post-larvae were collected on a $150 \mu \mathrm{m}$ mesh screen. The post-larvae were then maintained in two nutritional treatments in duplicate $130 \mu \mathrm{m}$ mesh screen downwelling tanks supplied with pre-filtered $(5 \mu \mathrm{m})$ and temperature controlled $\left(\approx 15-16^{\circ} \mathrm{C}\right)$ seawater at a flow rate $100 \mathrm{I} \mathrm{h}^{-1}$. The size of the downwelling tank's mesh screen size was adjusted to retain post-larvae until 68 days post-fertilization (dpf). Post-larvae were fed continuously with the same nutritional treatment (PTC and PTCR) at $2.5 \times 10^{9}$ cells day $^{-1}$. After $68 \mathrm{dpf}$, post-larvae from the two downwellers were pooled by treatment, sorted by size $(<1200 \mu \mathrm{m}, 1200-1500 \mu \mathrm{m},>1500 \mu \mathrm{m})$ and transferred to the Station Marine de Dinard (Muséum National d'Histoire Naturelle, France) for the flume experiments. Postlarvae were kept in two 164 I aquaria (one for each diet) supplied with flowing seawater at $18^{\circ} \mathrm{C}$ and were fed three times a day with one of the diets $\left(30\right.$ cells $\left.\mu l^{-1}\right)$. Post-larvae from each size class and diet were kept in individual downwellers (mesh size $500 \mu \mathrm{m}$ ) and three downwellers were kept in each aquarium.

\subsection{Experimental design}

To assess the influence of diet on the detachment level of post-larval to the substratum, we exposed scallops previously fed with either PTC or PTCR to various flow treatments in the racetrack HYCOBENTHOS flume at the Station Marine de Dinard. Detailed characteristics of the flume and the flow it generates can be found in Olivier (1997) and Jonsson et al. (2006). Briefly, BBL flows were generated within the flume (total length = $6 \mathrm{~m}$, width $=0.5 \mathrm{~m}$ ) via 14 vertical PVC (polyvinylchloride) disks $(0.8 \mathrm{~m}$ diameter) immersed in the water $(z=0.15 \mathrm{~m})$ and connected to a direct-power variable speed motor by a pulley system. This rotating system generates a quasi-steady unidirectional turbulent flow at the end of the straight section (length $=3.5 \mathrm{~m}$ ). To maximize the establishment of the BBL, we fixed a $6 \mathrm{~mm}$ thick roughened PVC plate to the whole straight section of the flume with alimentary silicone glue. This plate had a $5 \times 5 \mathrm{~cm}$ hole centered along the width and located at $3.175 \mathrm{~m}$ from the leading edge where we could attach the test plates. Before each flume trial, seawater temperature and salinity were measured and one attachment plate was gently placed in the flume to fill the hole in the straight PVC plate and to minimize any side effects. 
We tested the impact of increasing shear velocity on scallop detachment on batches of post-larvae $>1500 \mu \mathrm{m}$ that had been just fed PTC. Samples of approximately 100 postlarvae were collected and placed on a single PVC attachment plate $(5 \times 5 \times 0.6 \mathrm{~cm})$ for $30 \mathrm{~min}$. Plates had previously been sanded on one side to roughen the surface and therefore facilitate larval attachment and adhesion (Olivier et al. 2000). Post-larvae were then exposed to three increasing flow regimes that we refer to as rapid, rapid-gradual and gradual (Fig. 1). Each flow regime was tested three times (temporal replication). Scallop detachment was evaluated by taking a high resolution numerical picture (3008 $x$ 2000 pixels with a Nikon ${ }^{\mathrm{TM}}$ D70, Sur Marne, France) of the attachment plate at the beginning of the trial and between each step of increasing shear velocity $\left(\mathrm{cm} . \mathrm{s}^{-1}\right)$.

The influence of shell length, attachment period and shear velocity on detachment of post-larvae fed the two diets was tested on three size classes: $<1200 \mu \mathrm{m}, 1200-1500$ $\mu \mathrm{m}$ and $>1500 \mu \mathrm{m}$. Post-larvae of each diet (PTC and PTCR) and each size were placed on plate as already described for one of two attachment periods, 30 min or $12 \mathrm{~h}$. The post-larvae were then exposed to shear velocities with a first phase of high shear stress followed by a second phase of maximum shear velocity (Fig. 2) for a total test duration of 9 minutes. Each treatment was repeated three times (Fig. 2). Numerical pictures were taken before each trial and for shear velocities of 1.42 and $2.45 \mathrm{~cm} \mathrm{~s}^{-1}$.

All numerical pictures were analyzed with Image-Pro® Plus, version 5.0 for Windows ${ }^{\mathrm{TM}}$ (Silver Springs, MD, USA), to assess the abundance of post-larvae attached to the plate.

\subsection{Biochemical analysis}

Before flume experiments, 10000 scallops were sampled in duplicate for each analysis, which included organic matter, total lipids, proteins, carbohydrates, fatty acids and sterols. Because the number of post-larvae was limited, the three size classes were pooled for biochemical sampling. Samples for organic matter, total lipid, protein and carbohydrate analyses were kept at $-80^{\circ} \mathrm{C}$. For fatty acid and sterol determinations, samples were preserved in $6 \mathrm{ml}$ of chloroform:methanol $(2: 1, \mathrm{v} / \mathrm{v})$ and under nitrogen at $20^{\circ} \mathrm{C}$. All analyses were done in less than 2 months. The organic matter was calculated as the difference between the dry matter (weight of scallops after being ground and dried at $80^{\circ} \mathrm{C}$ for $24 \mathrm{~h}$ ), and the ash weight determined after heating the dried scallops to $450^{\circ} \mathrm{C}$ for $4 \mathrm{~h}$. Total lipid quantification was determined from the mass obtained after lipid extraction (Bligh and Dyer 1959). Carbohydrate and protein contents were measured colorimetrically (Lowry et al. 1951; Dubois et al. 1956) with a Kontron Uvikon $^{\mathrm{TM}} 941$ spectrophotometer (Bedforshire, UK).

For fatty acid characterization, lipid extracts were evaporated to dryness and recovered with three washings of $500 \mu \mathrm{l}$ of chloroform:methanol $(98: 2, \mathrm{v} / \mathrm{v})$. Neutral and polar lipids were separated by column chromatography on silica gel micro-columns $(30 \times 5 \mathrm{~mm}$ I.D., Kieselgel $70-230$ mesh) using chloroform:methanol $(98: 2, \mathrm{v} / \mathrm{v})$ to elute neutral lipids followed by methanol to elute polar lipids (Marty et al. 1992). A known amount of 23:0 (internal standard) was added to each lipid fraction. Lipids were trans-esterified under nitrogen using $\mathrm{BF}_{3} / \mathrm{CH}_{3} \mathrm{OH}(12 \%)$ for 10 minutes at $100^{\circ} \mathrm{C}$. Fatty acid methyl esters (FAME) were analyzed using a gas chromatograph ( $\mathrm{HP}^{\mathrm{TM}}$ 6890, Massy Cedex, France) equipped with an on-column injector, a DB-Wax $(30 \mathrm{~m} \times 0.25 \mathrm{~mm} ; 0.25 \mu \mathrm{m}$ film thickness) capillary column and a flame ionization detector. Hydrogen was used as the carrier gas at $2 \mathrm{ml} \mathrm{min}^{-1}$. Fatty acids were identified by comparing their retention times 
with known standards (37 component FAME mix, PUFA-3 and menhaden oil) and quantified with tricosanoic acid (23:0).

Finally, sterol profiles were analyzed on an aliquot of the neutral lipids transesterified using sodium methoxyde $(0.5 \mathrm{M}$ in methanol) at ambient temperature for $90 \mathrm{~min}$ (Soudant et al., 1998). Sterols were analyzed using a gas chromatograph (Chrompak ${ }^{\mathrm{TM}}$ 9002, Middelburg, The Netherlands) equipped with an on-column injector followed by a Restek Rtx65 capillary column $(15 \mathrm{~m} \times 0.25 \mathrm{~mm}, 0.25 \mu \mathrm{m}$ film thickness). Hydrogen was used as the gas carrier. Sterols were identified by comparing their retention times with standards and quantified with cholestane as an internal standard.

\subsection{Statistical analysis}

For the experiment measuring the impact of increasing flow regime, a repeated two-way ANOVA was conducted to determine differences in post-larval detachment as a function of increasing flow regimes (rapid, rapid-gradual and gradual) and shear stress $(0,0.37$, $0.44,1.05,1.42$ and $\left.2.45 \mathrm{~cm} \mathrm{~s}^{-1}\right)$. The unit of replication was the trial for each treatment $(N=3)$. For the experiment on the influence of flow velocity, shell length and attachment time on detachment of post-larvae fed the two diets, three-way repeated ANOVAs were applied for each diet with size of post-larvae $(<1200,1200-1500,>1500 \mu \mathrm{m})$, attachment periods (30 min, $12 \mathrm{~h})$ and shear stress $\left(0,1.42,2.45 \mathrm{~cm} \mathrm{~s}^{-1}\right.$, three level of repeated measurements). Mauchly's test $(\alpha=0.05)$ was used to assess whether datasets conformed to the sphericity assumption required for a repeated measure analysis. Diet was not included as a factor in a global statistical analysis because this treatment was not replicated. Data were arcsine square-root transformed to achieve homogeneity of variances. Residuals were screened for normality using the expected normal probability plot, and homogeneity of variance-covariance matrices was tested using the Levene test. Biochemical analyses between post-larvae fed with PTC or PTCR were compared by t-test. All analyses were carried out using SPSS ${ }^{\mathrm{TM}} 13.0$ for Windows (Chicago, IL, USA).

\section{Results}

\subsection{Flume experiments}

Flow regimes (Figure 1) had no effect on detachment of post-larval scallops fed PTC (Fig. 3, Table 1). By contrast, shear stress had a strong effect on detachment of scallops: more than $65 \%$ of scallops detaching when velocity exceeded $1.42 \mathrm{~cm} \mathrm{~s}^{-1}$ (Fig. 3 ). Thus, only the rapid regime was used for the second experiment measuring the effect of shear stress, scallop size and attachment period.

For post-larvae fed the PTC diet, the within-subject analysis indicated that only shear stress significantly affected the percent detachment, with no interactions with any other factors (Fig. 4, Table 2). The between-subject analysis revealed a significant effect of the attachment period on the percent detachment of scallops (Table 2) whereas size and its interaction with attachment period were not significant (Table 2). Similar detachment values were observed between $1.42 \mathrm{~cm} \mathrm{~s}^{-1}$ and $2.45 \mathrm{~cm} \mathrm{~s}^{-1}$, with mean values of $36.2 \pm 15 \%$ for $12 \mathrm{~h}$ attachment periods and $76.1 \pm 10.5 \%$ for 30 min periods (Fig. 4 ). 
For post-larvae fed the PTCR diet, we noted a combined effect of shear stress, size, and attachment period on the percent detachment of scallop post-larvae (Table 2). Significant detachment percentages were observed at shear stress $=1.42 \mathrm{~cm} \mathrm{~s}^{-1}$ and levels were similar level at $2.45 \mathrm{~cm} \mathrm{~s}^{-1}$, with mean values of $57.3 \pm 12.2 \%$ for $12 \mathrm{~h}$ attachment periods and $84.9 \pm 9.3 \%$ for 30 min periods (Fig. 4).

\subsection{Biochemical measures}

Organic matter, protein and carbohydrate concentrations in scallops fed PTC were similar to those of post-larvae fed PTCR at the onset of the flume experiment (Table 3). However, lipid levels in scallops fed PTCR was slightly but significantly lower $(P=0.049)$ than that of animals fed PTC (Table 3). The higher level of lipid in post-larvae fed PTC was reflected by higher levels of total fatty acid in the neutral and polar fractions of lipids (Table 4) and in the sterol classes (Table 5). In relative concentrations of fatty acids measured between post-larvae fed either diet, we observed significant differences only in the neutral fraction. Level of AA was higher in scallops fed PTCR than those fed PTC. Inverse was observed with EPA, as scallops fed PTC showed higher level of EPA than those fed PTCR (Table 4). Furthermore, we observed some differences in sterol composition (see t-test results in Table 5). Scallops fed the PTC diet showed higher levels of cholesterol, campesterol and $\beta$-sitosterol than scallops fed PTCR (Table 5). Only brassicasterol was higher in post-larvae fed PTCR compared to those fed PTC (Table 5).

\section{Discussion}

We observed that the critical shear velocity needed to detach $P$. maximus post-larvae was about $1.42 \mathrm{~cm} \mathrm{~s}^{-1}$, at which point about $80 \%$ of the individuals detached when the attachment period had been only $30 \mathrm{~min}$. No effect of shell length was observed for the size classes tested. When post-larvae were allowed to settle for $12 \mathrm{~h}$, the detachment percentage at $1.42 \mathrm{~cm} \mathrm{~s}^{-1}$ significantly decreased to less than $60 \%$, especially for postlarvae fed the PTC diet: these scallops had a mean detachment level of only $36.2 \pm 15 \%$.

\subsection{Shear velocity}

In our experiment, shear velocity affected the percent detachment of $P$. maximus fed the two experimental diets. The detachment of post-larval scallops was high with shear stress greater than $1.42 \mathrm{~cm} \mathrm{~s}^{-1}$ irrespective of scallop size. Thus, for each diet, the detachment level is generally similar between shear velocity of 1.42 and $2.45 \mathrm{~cm} \mathrm{~s}^{-1}$ for all size of post-larvae and attachment period measured. This similarity in detachment levels with an important shear velocity increase could be explained by an increase in byssal thread production in reaction to the flow velocity increment. Many studies have investigated the effect of flow velocity on attachment strength via mucus threads-a few have been on polychaetes (Olivier and Retière, 2006), but most have considered blue mussels from the Mytilus genus. The number of byssal threads and the strength of byssus attachment have been found to be significantly affected by flow velocity (Dolmer and Svane, 1994). It has been generally assumed that mussels increase their thread production following periods of increased wave action (Carrington, 2002; Moeser et al., 
2004; Moeser and Carrington, 2006) and turbulence (Lachance et al., 2008). However, Moeser et al. (2006) observed that increased flow generated in a flume consistently reducing thread production of mussels. Flow velocity can influence the settlement of many invertebrate taxa. Mullineaux and Garland (1993) investigated the effect of boundary-layer flows on the settlement of several common encrusting species including the hydroid Tubularia crocea, the bryozoans Bugula turrita and Schizoporella unicornis, and the tube-building polychaete Hydroides dianthus. Settlement responses to flow were strongly species-specific, with $T$. crocea selecting regions of both high turbulence and strong shear stress, and $S$. unicornis settling almost exclusively in regions of high shear stress. B. turrita settled most prominently in regions of reduced shear stress, exhibiting settlement patterns that closely approximated predictions from a passive particle model. $H$. dianthus showed a moderate avoidance of regions with high shear stress.

\subsection{Diet}

Effect of factors influencing detachment of post-larvae scallop was different depending to diet. For post-larvae fed PTC diet, analysis indicated that only shear stress significantly affected detachment. For post-larvae fed the PTCR diet, results showed significant interaction of shear stress, size and attachment period. The detachment of scallop postlarvae exposed to unidirectional turbulent flume flows were lower in post-larvae fed with the PTC diet. Post-larvae scallop fed with PTC diet accumulated higher level of lipids. This higher level of lipids contents reflects more accumulation of energetic reserves, as sum of fatty acids in neutral fraction was higher, but also in fatty acids incorporated in cells membrane (polar fraction) and the sum of all sterol classes. These differences observed in 45 dpf post-larvae in Gagné et al. (2010) were preserved in post-larvae of $68 \mathrm{dpf}$ in this experiment. Previous study suggested that energy costs for byssal thread production were relatively high with values about $8 \%$ of the mussel Mytilus edulis total energy costs as well as high proportions of the carbon $(44 \%)$ and nitrogen $(21 \%)$ budgets (Hawkins and Bayne, 1985) and a maximum of $14 \%$ of the energy budget of pectinid Chlamys islandica (Vahl, 1981). The energy assimilated from available food is allocated to different metabolic functions including growth, maintenance or production of inert tissue like byssal threads (Hawkins and Bayne, 1991). In high turbulent environment, allocation of energy to byssal thread production could be promoted to maintain animals attached. As thread production is often considered to be costly in terms of energy requirements (Pieters et al., 1980; Zardi et al., 2007), is it not surprising that scallop post-larvae having higher lipids content still attached at higher flow. In this experience, the small size of scallop post-larvae has limited the direct measure of byssal thread production and attachment strength has been estimated by the force due to flow. Thus, our measures report indirect information suggesting that scallop post-larvae having higher available energy reserves could produce byssal threads in larger numbers and/or in less time and/or with higher strength.

Diet affects fatty acid profiles, but only in the neutral fraction of lipids with higher accumulation of AA and lower level of EPA, in post-larvae fed PTCR. These results are related to the addition of $R$. salina containing higher level of AA and lower content of EPA (Soudant et al., 1998; Tremblay et al., 2007). Contrary to Gagné et al (2010) observing similar changes in neutral and polar lipids of post-larvae fed PTCR and PTC until $45 \mathrm{dpf}$, we observe no change in polar lipids when post-larvae attained $68 \mathrm{dpf}$. These results suggest that the increase of post-larvae size could stimulate accumulation of AA in polar lipids. We observed that AA level of polar lipids was over $4.5 \%$ of total 
fatty acid for the two diets and similar to higher level observed in Gagné et al. (2010), even if neutral fraction of post-larvae fed with PTC showed only $2.2 \%$ of AA. Greater biochemical variations of specific lipids were mostly observed in sterol composition and could be related to byssal thread production. Is it known that sterol is needed for the development of bivalves, particularly in juveniles' stages (Wikfors et al., 1996; Park et al., 2002). Since the mollusks have a limited capacity for sterol biosynthesis (Goad, 1981), the presence of different phytosterols in post-larvae reflect the variety of phytoplankton food sources and may also be regarded as an indication of the complex metabolic transformations undergone after ingestion (Knauer, 1998). The best compromise between larval growth and settlement rates was observed with a diet rich in C24 ethyl sterol, $\beta$-sitosterol and stigmasterol. (Soudant et al., 1998). From these three sterol group, only $\beta$-sitosterol was higher in post-larvae showing higher resistance to detachment. Brassicasterol, which was the main sterol found in $R$. salina (Tremblay et al., 2007), was two time higher in post-larvae fed PTCR which were less resistant to detachment.

\subsection{Attachment period}

Attachment period significantly affected the detachment percentage of post-larval scallops subjected to flow velocities over $1.42 \mathrm{~cm} \mathrm{~s}^{-1}$, with the percent detachment higher following an attachment period of 30 minutes. Eckman et al. (1990) described the relationships between the duration of antennular attachment of Balanus amphitrite cyprids and forces associated with detachment, which were assessed in a small flume. Drag forces associated with detachment were significantly and positively correlated with the duration of attachment until $10^{3} \mathrm{~s}$. The forces associated with $B$. amphitrite cyprid detachment increased with the individual's time of contact with the surface for periods greater than $10^{3} \mathrm{~s}$. This time dependence may be caused by the continuous formation of both chemical bonds between the proteinaceous adhesive and the Plexiglas substratum or perhaps by cross-links within the adhesive itself. This force-time dependence suggests that barnacle settlement intensities may vary spatially or temporally according to variations in the temporal pattern of fluid forces (Eckman et al., 1990). We can expect similar processes of attachment force and time dependence in the field for $P$. maximus post-larvae.

\section{Conclusion}

In this study, we investigated the effect of flow velocity on the percent detachment of Pecten maximus larvae produced in hatchery and fed two diets. The flow velocity (shear stress) positively affected the detachment percentage of post-larvae. While it is difficult to clearly assess the impact of diet on percent detachment, our results suggest that a higher accumulation of lipids and brassicasterol enrichment of sterol negatively affect attachment strength of Pecten maximus post-larvae submitted to shear velocities under $2.45 \mathrm{~cm} \mathrm{~s}^{-1}$. 


\section{Acknowledgements}

The authors would like to thank Jean-René le Coz from the Laboratoire de Physiologie des mollusques, IFREMER Centre de Brest, for help in biological analyses. Thanks to Laure Devine for English revision. This project was supported by the Canada Research Chair program and the Natural Sciences and Engineering Research Council of Canada to RT.

\section{References}

Andersen, S., Christophersen, G., Magnesen, T., 2011. Spat production of the great scallop (Pecten maximus): A roller coaster. Can. J. Zool. 89, 579-598.

Arrieche, D., Maeda-Martinez, A.N., Farias-Sanchez, J.A., Saucedo, P.E., 2010. Biological performance of the penshell Atrina maura and mussel Mytella strigata under different water flow regimes. Ciencias Mar. 36, 237-248.

Bishop, C.D., Huggett, M.J., Heyland, A., Hodin, J., Brandhorst, B.P. 2006. Interspecific variation in metamorphic competence in marine invertebrates: the significance for comparative investigations into the timing of metamorphosis. Integr. Comp. Biol. 46, 662-682.

Bligh, E.G., Dyer, W.J. 1959. A rapid method of total lipid extraction and purification. Can. J. Biochem. Physiol. 37, 911-917.

Caddy, J.F. 1972. Progresive loss of byssus attachment with size in the sea scallop, Placopecten magellanicus (Gmelin). J. Exp. Mar. Biol. Eco.I 9, 179-190.

Carrington, E. 2002. Seasonal variation in the attachment strength of blue mussels: Causes and consequences. Limnol. Oceanogr. 47, 1723-1733.

Christophersen, G., Strand, O. (2003) Effect of reduced salinity on the great scallop (Pecten maximus) spat at two rearing temperatures. Aquaculture 215, 79-92.

Cragg, S.M., Crisp, D.J. 1991. The biology of scallop larvae. In: Shumway, S.E., Parsons, G.J. (Eds.), Scallops: Biology, ecology and aquaculture, Vol. 21, Elsevier, Amsterdam, pp. 75-122.

Crisp, D.J. 1974. Factors influencing the settlement of marine invertebrate larvae. In: Grant, P.T., Mackie, A.M., (Eds.), Chemoreception in marine organisms, Academic Press, New York, pp. 177-265.

Culver, C.S., Richards, J.B., Page, H.M. 2006. Plasticity of attachment in the purplehinge rock scallop, Crassadoma gigantea: Implications for commercial culture. Aquaculture 254, 361-369.

Delaunay, F., Marty, Y., Moal, J., Samain, J.-F. 1993. The effect of monospecific algal diets on growth and fatty acid composition of Pecten maximus (L.) larvae. J. Exp. Mar. Biol. Ecol. 173, 163-179.

Dolmer, P., Svane, I. 1994. Attachment and orientation of Mytilus edulis L. in flowing water. Ophelia 40, 63-74.

Dubois, M., Gillies, K.A., Hamilton, J.K., Rebers, P.A., Smith, F. 1956. Colorimetric method for the determination of carbohydrates and related substances. Anal. Chem. 28, 350-356.

Eckman, J.E. 1987. The role of hydrodynamics in recruitment, growth, and survival of Argopecten irradians (L.) and Anomia simplex (D'Orbigny) within eelgrass meadows. J. Exp. Mar. Biol. Ecol. 106, 165-191. 
Eckman, J.E., Savidge, W.B., Gross, T.F. 1990. Relationship between duration of cyprid attachment and drag forces associated with detachment of Balanus amphitrite cyprids. Mar. Biol. 107, 111-118.

Gagné, R., Tremblay, R., Pernet, F., Miner, P., Samain, J.-F., Olivier, F. 2010. Lipid requirements of the scallop Pecten maximus (L.) during larval and post-larval development in relation to addition of Rhodomonas salina in diet. Aquaculture 309, 212-221.

Goad, L.J. 1981. Sterol biosynthesis and metabolism in marine invertebrates. Pure Appl. Chem. 53, 837-852.

Gruffyd, L.I., Budiman, A., Nott. J.A. 1979. The ultrastructure of the byssus and the byssus glands in Chlamys varia L. (Lamellibranchia). J. Mar. Biol. Ass. U.K. 59, 597-603.

Hadfield, M.G., Carpizo-Ituarte, E.J., del Carmen, K., Nedved, B.T. 2001. Metamorphic competence, a major adaptive convergence in marine invertebrate larvae. Am. Zool. 41, 1123-1131.

Hawkins, A.J.S., Bayne, B.L. 1985. Seasonal variation in the relative utilization of carbon and nitrogen by the mussel Mytilus edulis: budgets, conversion efficiencies and maintenance requirements. Mar. Ecol. Prog. Ser. 25, 181-188.

Hawkins, A.J.S., Bayne, B. 1991. Nutrition of marine mussels: factors influencing the relative utilizations of protein and energy. Aquaculture 94, 177-196.

Knauer, J., Kerr, R.G., Lindley, D., Southgate, P.C. 1998. Sterol metabolism of Pacific oyster (Crassostrea gigas) spat. Com. Biochem. Physiol. 119B, 81-84.

Jonsson, P.R., van Duren, L.A., Amielh, M., Asmus, R., Aspden, R.J., Daunys, D., Friedrichs, M., Friend, P.L., Olivier, F., Pope, N., Precht, E., Sauriau, P.G., Schaaff, E. 2006. Making water flow: a comparison of the hydrodynamic characteristics of 12 different benthic biological flumes. Aquat. Ecol. 40, 409-438.

Lachance, A.A., Myrand, B., Tremblay, R., Koutitonsky, V., Carrington, E. 2008. Biotic and abiotic factors influencing attachment strength of blue mussels Mytilus edulis in suspended culture. Aquat. Biol. 2, 119-129.

Larsson, A.I., Jonsson, P.R. 2006. Barnacle larvae actively select flow environments supporting post-settlement growth and survival. Ecology 87, 1960-1966.

Lowry, O.H., Rosebrough, N.J., Farr, A.L., Randall, R.J. 1951. Protein measurement with the Folin phenol reagent. J. Biol. Chem. 193, 265-275.

Magnesen, T., Jacobsen, A., 2012. Effect of water recirculation on seawater quality and production of scallop (Pecten maximus) larvae. Aquacultural Engineering. 47, 16.

Mahéo, R. 1968. Observations sur l'anatomie et le fonctionnement du complexe byssogène de Chlamys varia L. Cah. Biol. Mar. 9, 373-379.

Marty, Y., Delaunay, F., Moal, J., Samain, J.-F. 1992. Changes in the fatty acid composition of Pecten maximus (L.) during larval development. J. Exp. Mar. Biol. Ecol. 163, 221-234.

Mesías-Gansbiller, C., Bendimerad, M.E.A., Román, G., Pazos, A.J., Sánchez, J.L., Pérez-Parallé, M.L., 2008. Settlement behavior of black scallop larvae (Chlamys varia, L.) in response to GABA, epinephrine and IBMX. J. Shellfish Res. 27, 261264.

Minchin, D. 1992. Biological observations on young scallops, Pecten maximus. J. Mar. Biol. Ass. U.K. 72, 807-819.

Moeser, G., Leba, H., Carrington, E. 2004. When mussels don't go with the flow: Seasonal variation in byssal thread production and mechanics. Integr. Comp. Biol. 44, 608-608. 
Moeser, G.M., Carrington, E. 2006. Seasonal variation in mussel byssal thread mechanics. J. Exp. Biol. 209, 1996-2003.

Moeser, G.M., Leba, H., Carrington, E. 2006. Seasonal influence of wave action on thread production in Mytilus edulis. J. Exp. Biol. 209, 881-890.

Mullineaux, L.S., Garland, E.D. 1993. Larval recruitment in response to manipulated field flows. Mar. Biol. 116, 667-683.

Olivier, F. 1997. Régulation des populations de recrues en régime mégatidal : effet du couplage physique-biologie en couche limite benthique. PhD thesis, Université de Rennes 1, Rennes, 135 p.

Olivier, F., Retière, C. 2006. How to leave or stay on the substratum when you can't swim? Evidence of the role of mucus thread secretion by postlarvae of Pectinaria koreni (Malmgren) in still water flume experiments. Aquat. Ecol. 40, 503-519.

Olivier, F., Tremblay, R., Bourget, E., Rittschof, D. 2000. Barnacle settlement: field experiments on the influence of larval supply, tidal level, biofilm quality and age of Balanus amphitrite (Darwin) cyprids. Mar. Ecol. Prog. Ser. 199, 185-204.

Paul, J.D. 1980. Upper temperature tolerance and the effects of temperature on byssus attachment in the queen scallop Chlamys opercularis (L.). J. Exp. Mar. Biol. Ecol. 46, 41-50.

Park, D,W., Jo, Q., Lim, H.J., Véron, B. 2002. Sterol composition of dark-grown Isochrysis galbana and its implication in the seed production of Pacific oyster, Crassostrea gigas. J. Appl. Phycol. 14, 351-355.

Pawlik, J.R. 1992. Chemical ecology of the settlement of benthic marine invertebrates. Oceanogr. Mar. Biol. 30, 273-335.

Pechenik, J.A. 1990. Delayed metamorphosis by larvae of benthic marine invertebrates-does it occur - is there a price to pay. Ophelia 32, 63-94.

Pechenik, J.A. 2006. Larval experience and latent effects-metamorphosis is not a new beginning. Integr. Comp. Biol. 46, 323-333.

Pieters, H., Kluytmans, J.H., Zandee, D.I., Cadee, G.C. 1980. Tissue composition and reproduction of Mytilus edulis in relation to food availability. Neth. J. Sea. Res. 14, 349-361.

Powers, S.P., Kittinger, J.N. 2002. Hydrodynamic mediation of predator-prey interactions: differential patterns of prey susceptibility and predator success explained by variation in water flow. J. Exp. Mar. Biol. Ecol. 273, 171-187.

Qian, P.-Y. 1999. Larval settlement of polychaetes. Hydrobiologia. 402, 239-253.

Rupp, G.S., Parsons, G.J. 2004. Effects of salinity and temperature on the survival and byssal attachment of the lion's paw scallop Nodipecten nodosus at its southern distribution limit. J. Exp. Mar. Biol. Ecol. 309, 173-198.

Soudant, P., Le Coz, J.-R., Marty, Y., Moal, J., Robert, R., Samain, J.-F. 1998. Incorporation of microalgae sterols by scallop Pecten maximus (L.) larvae. Comp. Bioch. Physiol. 119A, 451-457.

Thiyagarajan, V. 2010. A review on the role of chemical cues in habitat selection by barnacles: New insights from larval proteomics. J. Exp. Mar. Biol. Ecol. 392, 2236.

Thorson, G. 1950. Reproductive and larval ecology of marine bottom invertebrates. Biol. Rev. 25, 1-45.

Tremblay, R., Olivier, F., Bourget, E., Rittschof, D. 2007a. Physiological condition of Balanus amphitrite cyprid larvae determines habitat selection success. Mar. Ecol. Prog. Ser. 340, 1-8.

Tremblay, R., Cartier, S., Miner, P., Pernet, F., Quéré, C., Moal, J., Muzellec, M.-L., Mazuret, M., Samain, J.-F. 2007b. Effect of Rhodomonas salina addition to a 
standard hatchery diet during the early ontogeny of the scallop Pecten maximus. Aquaculture 262, 410-418.

Vahl, O. 1981. Energy transformations by the Iceland scallop, Chlamys islandica (O.F. Müller) from $170^{\circ} \mathrm{N}$. I. The age-specific energy budget and net growth efficiency. J. Exp. Mar. Biol. Ecol. 53, 182-196.

Wikfors, G.H., Patterson, G.W., Ghosh, P., Lewin, R.A., Smith, B.C., Alix, J.H. 1996. Growth of post-set oysters, Crassostrea virginica, on high-lipid strains of algal flagellates Tetraselmis spp. Aquaculture 143, 411-419.

Zardi, G.I., McQuaid, C.D., Nicastro, K.R. 2007. Balancing survival and reproduction: seasonality of wave action, attachment strength and reproductive output in indigenous Perna perna and invasive Mytilus galloprovincialis mussels. Mar. Ecol. Prog. Ser. 334, 155-163.

Tables

Table 1. Summary of the two-way repeated ANOVAs on the effects of increased flow regime and shear velocity on percent detachment of post-larval scallop fed PTC at 68 dpf. Bold indicates a significant effect.

\begin{tabular}{lcccr}
\hline Source of variance & df & Mean Square & F & P \\
\hline Within subjects analysis & & & & \\
$\quad$ Shear velocity & 1 & 40933 & 417 & $<\mathbf{0 . 0 0 1}$ \\
$\quad$ Shear velocity $\times$ increased flow regime & 2 & 44.9 & 0.46 & 0.653 \\
$\quad$ Error (shear velocity) & 6 & 98.1 & & \\
Between subjects analysis & & & & \\
$\quad$ increased flow regime & 2 & 274 & 3.1 & 0.119 \\
$\quad$ Error & 6 & 88.6 & & \\
\hline
\end{tabular}


Table 2. Summary of the three-way repeated ANOVAs of the effects of size, attachment period and shear velocity on percent detachment of post-larval scallops at $68 \mathrm{dpf}$ fed PTC or PTCR. See text for diet descriptions. Bold indicates a significant effect.

PTC

\begin{tabular}{|c|c|c|c|c|}
\hline Source of variance & df & Mean Square & $\mathrm{F}$ & $p$ \\
\hline \multicolumn{5}{|l|}{ Within subjects analysis } \\
\hline Shear velocity & 1 & 635 & 32.3 & $<0.001$ \\
\hline Shear velocity $\times$ Size & 2 & 6.9 & 0.35 & 0.709 \\
\hline Shear velocity $\times$ Attachment period & 1 & 0.004 & 0.000 & 0.988 \\
\hline Shear velocity $\times$ Size $\times$ Attachment period & 2 & 11.9 & 0.61 & 0.561 \\
\hline Error (shear velocity ) & 12 & 19.7 & & \\
\hline \multicolumn{5}{|l|}{ Between subjects analysis } \\
\hline Size & 2 & 149 & 0.44 & 0.656 \\
\hline Attachment period & 1 & 14299 & 41.7 & 0.001 \\
\hline Size $\times$ Attachment period & 2 & 487 & 1.42 & 0.279 \\
\hline Error & 12 & 342 & & \\
\hline
\end{tabular}

PTCR

\begin{tabular}{|c|c|c|c|c|}
\hline Source of variance & df & Mean Square & $\mathrm{F}$ & $\mathrm{P}$ \\
\hline \multicolumn{5}{|l|}{ Within subjects analysis } \\
\hline Shear velocity & 1 & 613 & 56.7 & $<0.001$ \\
\hline Shear velocity $\times$ Size & 2 & 69.6 & 6.4 & 0.013 \\
\hline Shear velocity $\times$ Attachment period & 1 & 53.5 & 4.9 & 0.046 \\
\hline Shear velocity $\times$ Size $\times$ Attachment period & 2 & 68 & 6.3 & 0.014 \\
\hline Error (shear velocity) & 12 & 10.8 & & \\
\hline \multicolumn{5}{|l|}{ Between subjects analysis } \\
\hline Size & 2 & 112 & 0.453 & 0.646 \\
\hline Attachment period & 1 & 6855 & 27.7 & $<0.001$ \\
\hline Size $\times$ Attachment period & 2 & 302 & 1.2 & 0.329 \\
\hline Error & 12 & 248 & & \\
\hline
\end{tabular}


Table 3. Pecten maximus post-larvae fed PTC or PTCR: Organic matter (\%) and biochemical content $\left(\mathrm{mg} \mathrm{g}^{-1}\right.$ ash free dry weight) of post-larvae at $68 \mathrm{dpf}$. Mean \pm SD. See text for diet descriptions. Bold indicates a significant effect.

\begin{tabular}{lccc}
\hline & PTCR & PTC & t-test $(\mathrm{df}=4)$ \\
\hline Organic matter & $15.6 \pm 5.2$ & $15.4 \pm 3.9$ & $t=-0.21, P=0.85$ \\
Protein & $596 \pm 43$ & $561 \pm 133$ & $t=-0.69, P=0.53$ \\
Lipid & $140 \pm 29$ & $154 \pm 16$ & $t=2.79, P=0.049$ \\
Carbohydrate & $71.1 \pm 14.3$ & $59.8 \pm 17.7$ & $t=-0.87, P=0.44$ \\
\hline
\end{tabular}

Table 4. Fatty acid composition of the polar and neutral lipid fractions in $68 \mathrm{dpf}$ Pecten maximus post-larvae fed PTCR and PTC diets. Data are expressed as \% of total fatty acids (TFA) except for the total fatty acid concentration, which is in pg individual ${ }^{-1}$. Mean \pm SD. See text for diet descriptions. Bold indicates a significant effect.

\begin{tabular}{|c|c|c|c|c|c|c|}
\hline & \multicolumn{3}{|c|}{ Polar fraction } & \multicolumn{3}{|c|}{ Neutral fraction } \\
\hline & PTCR & PTC & t-test $(\mathrm{df}=2)$ & PTCR & PTC & t-test $(\mathrm{df}=2)$ \\
\hline $14: 0$ & $1.7 \pm 0.4$ & $1.6 \pm 0.1$ & $t=-0.36, P=0.751$ & $8.6 \pm 1.1$ & $10.5 \pm 1.6$ & $t=1.31, P=0.321$ \\
\hline 16:0 & $12.4 \pm 0.1$ & $12.5 \pm 0.9$ & $t=-1.35, P=0.308$ & $14.1 \pm 1.2$ & $14.1 \pm 0.5$ & $t=0.62, P=0.956$ \\
\hline 18:0 & $6.2 \pm 0.9$ & $7.2 \pm 0.5$ & $t=1.33, P=0.354$ & $2.4 \pm 0.5$ & $2.1 \pm 0.3$ & $t=-1.07, P=0.397$ \\
\hline$\Sigma$ SFA & $20.4 \pm 0.5$ & $21.4 \pm 0.2$ & $t=0.18, P=0.874$ & $25.2 \pm 1.8$ & $26.6 \pm 1.8$ & $t=0.88, P=0.471$ \\
\hline $16: 1(n-7)$ & $4.4 \pm 0.8$ & $3.6 \pm 1.4$ & $t=-0.69, P=0.559$ & $14.2 \pm 2.5$ & $11.8 \pm 4.7$ & $t=-0.61, P=0.602$ \\
\hline $18: 1(n-9)$ & $1.8 \pm 2.6$ & $3.1 \pm 0.3$ & $t=0.72, P=0.548$ & $4.9 \pm 0.1$ & $4.6 \pm 0.7$ & $t=-0.71, P=0.608$ \\
\hline $18: 1(n-7)$ & $7.1 \pm 0.6$ & $5.6 \pm 0.9$ & $t=-2.02, P=0.180$ & $5.8 \pm 0.1$ & $5,4 \pm 0.1$ & $t=-0.71, P=0.550$ \\
\hline $20: 1(n-9)$ & $0.6 \pm 0.9$ & $1.7 \pm 0.3$ & $t=1.68, P=0.234$ & $0.7 \pm 0.1$ & $0.5 \pm 0.2$ & $t=1.25, P=0.338$ \\
\hline$\sum$ MUFA & $15.6 \pm 1.6$ & $15.5 \pm 2.5$ & $t=-0.44, P=0.734$ & $25.6 \pm 2.3$ & $22.9 \pm 3.3$ & $t=-1.28, P=0.329$ \\
\hline $18: 2(n-6)$ & $4.1 \pm 1.7$ & $4.2 \pm 1.6$ & $t=0.07, P=0.951$ & $8.9 \pm 2.4$ & $9.1 \pm 4.2$ & $t=-1.33, P=0.406$ \\
\hline $18: 3(n-6)$ & $0.6 \pm 0.2$ & $0.7 \pm 0.3$ & $t=0.43 P=0.509$ & $1.2 \pm 0.2$ & $1.9 \pm 0.2$ & $t=3.77, P=0.064$ \\
\hline $18: 3(n-3)$ & $1.1 \pm 0.4$ & $1.6 \pm 0.6$ & $t=1.08, P=0394$ & $3.3 \pm 0.8$ & $4.5 \pm 2.3$ & $t=0.73, P=0.543$ \\
\hline $18: 4(n-3)$ & $2.2 \pm 0.3$ & $2.4 \pm 0.3$ & $t=0.32, P=0.778$ & $3.6 \pm 0.1$ & $5.6 \pm 1.1$ & $t=2.52, P=0.128$ \\
\hline $20: 4(n-6)(A A)$ & $4.8 \pm 0.3$ & $4.4 \pm 0.8$ & $t=-0.71, P=0551$ & $4.1 \pm 0.1$ & $2.2 \pm 0.4$ & $t=-8.87, P=0.012$ \\
\hline $20: 5(n-3)(E P A)$ & $9.9 \pm 0.1$ & $10.61 \pm 1.9$ & $t=-0.16, P=0.886$ & $10.7 \pm 0.1$ & $12.8 \pm 0.1$ & $t=-5.83, P=0.049$ \\
\hline $22: 4(n-9) t$ & $4.6 \pm 0.6$ & $3.6 \pm 0.8$ & $t=0.69, P=0.557$ & $1.2 \pm 0.1$ & $1.1 \pm 0.1$ & $t=-2.56, P=0.167$ \\
\hline $22: 5(n-6)$ & $4.1 \pm 0.4$ & $5.0 \pm 0.6$ & $t=-1.35, P=0313$ & $1.2 \pm 0.1$ & $1.3 \pm 0.1$ & $t=-2.01, P=0.200$ \\
\hline $22: 6(n-3)(D H A)$ & $23.4 \pm 1.7$ & $20.4 \pm 1.8$ & $t=-2.51, P=0.129$ & $7.6 \pm 0.2$ & $7.1 \pm 0.2$ & $t=-3.33, P=0.080$ \\
\hline$\sum$ PUFA & $60.6 \pm 2.6$ & $56.6 \pm 3.1$ & $t=-1.11, P=0.386$ & $49.0 \pm 0.1$ & $43.4 \pm 1.1$ & $t=0.37, P=0.748$ \\
\hline$\sum(n-6)$ & $17.3 \pm 2.9$ & $14.3 \pm 1.7$ & $t=0.35, P=0.761$ & $19.0 \pm 0.1$ & $12.8 \pm 0.7$ & $t=-0.81, P=0.943$ \\
\hline$\Sigma(n-3)$ & $40.4 \pm 1.6$ & $39.5 \pm 4.8$ & $t=-1.73, P=0322$ & $27.7 \pm 0.2$ & $27.8 \pm 0.8$ & $t=3.13, P=0.089$ \\
\hline TFA (pg individual ${ }^{-1}$ ) & $42.5 \pm 1.85$ & $75.6 \pm 11.8$ & $t=5.92, P=0.049$ & $69.7 \pm 9.21$ & $155.5 \pm 30.5$ & $t=13.2, P=0.006$ \\
\hline
\end{tabular}


Table 5. Sterol composition in $68 \mathrm{dpf}$ Pecten maximus post-larvae fed PTCR and PTC diets. Data are expressed as \% of total sterols except for the total sterol concentration, which is in $\mathrm{pg}$ individual ${ }^{-1}$. Mean $\pm \mathrm{SD}$. See text for diet descriptions. Bold indicates a significant effect.

\begin{tabular}{lrrr}
\hline & \multicolumn{1}{c}{ PTCR } & \multicolumn{1}{c}{ PTC } & \multicolumn{1}{c}{ t-test $(\mathrm{df}=2)$} \\
\hline Cholesterol & $17.0 \pm 3.7$ & $27.9 \pm 2.5$ & $t=-5.16, P=\mathbf{0 . 0 3 6}$ \\
Brassicasterol & $27.0 \pm 3.8$ & $13.0 \pm 0.5$ & $t=5.21, P=\mathbf{0 . 0 3 5}$ \\
Desmosterol & $2.4 \pm 0.4$ & $2.6 \pm 0.5$ & $t=-0.39, P=0.736$ \\
Campesterol & $5.0 \pm 0.1$ & $6.3 \pm 0.2$ & $t=-8.91, P=\mathbf{0 . 0 1 2}$ \\
24-methylene-cholesterol & $2.8 \pm 0.3$ & $2.7 \pm 0.3$ & $t=0.26, P=0.821$ \\
Stigmasterol & $14.6 \pm 0.4$ & $15.1 \pm 0.3$ & $t=-1.37, P=0.306$ \\
4a -methylporiferasterol & $2.8 \pm 0.5$ & $2.9 \pm 0.3$ & $t=-0.27, P=0.809$ \\
$\beta$-sitosterol & $12.3 \pm 1.9$ & $17.3 \pm 2.0$ & $t=-7.1, P=0.019$ \\
Fucosterol & $4.1 \pm 1.2$ & $5.7 \pm 0.7$ & $t=-1.67, P=0.238$ \\
Methylpavlovol & $9.5 \pm 1.3$ & $10.5 \pm 0.3$ & $t=-1.11, P=0.383$ \\
Ethylpavlovol & $1.8 \pm 0.1$ & $2.1 \pm 0.6$ & $t=-0.89, P=0.467$ \\
Total (pg individual ${ }^{-1}$ ) & $30.8 \pm 3.4$ & $48.3 \pm 0.8$ & $t=-6.99, P=0.020$ \\
\hline
\end{tabular}

\section{Figures}

Figure 1. Experimental design for the experiment on increases in flow regimes.

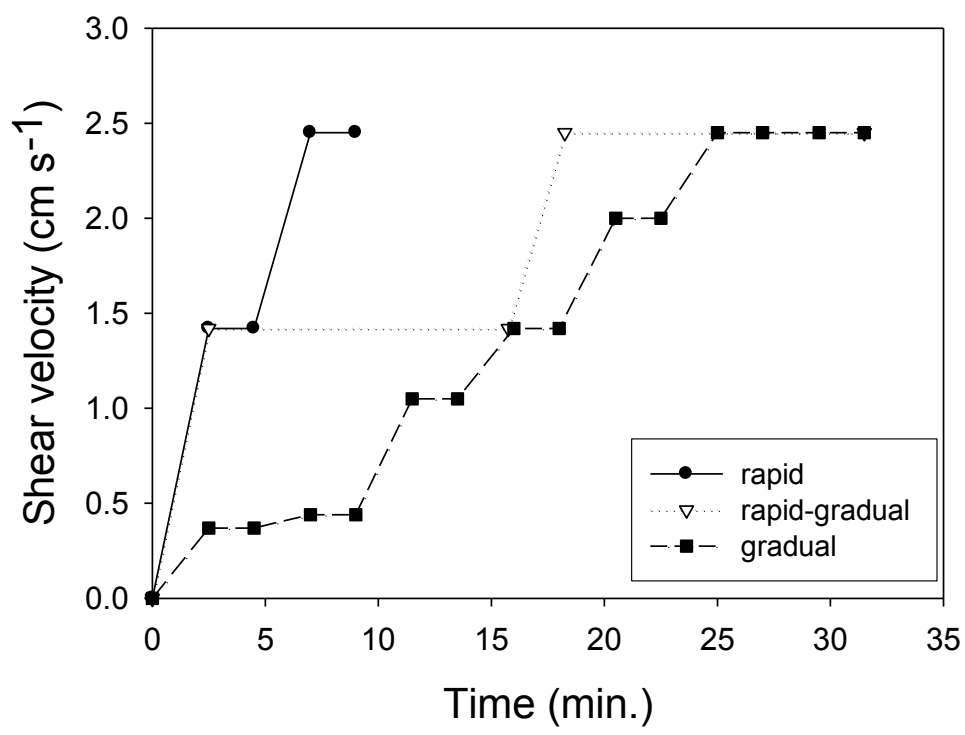


Figure 2. Experimental design for benthic biological flume experiments on post-larval scallop attachment. See text for diet descriptions.
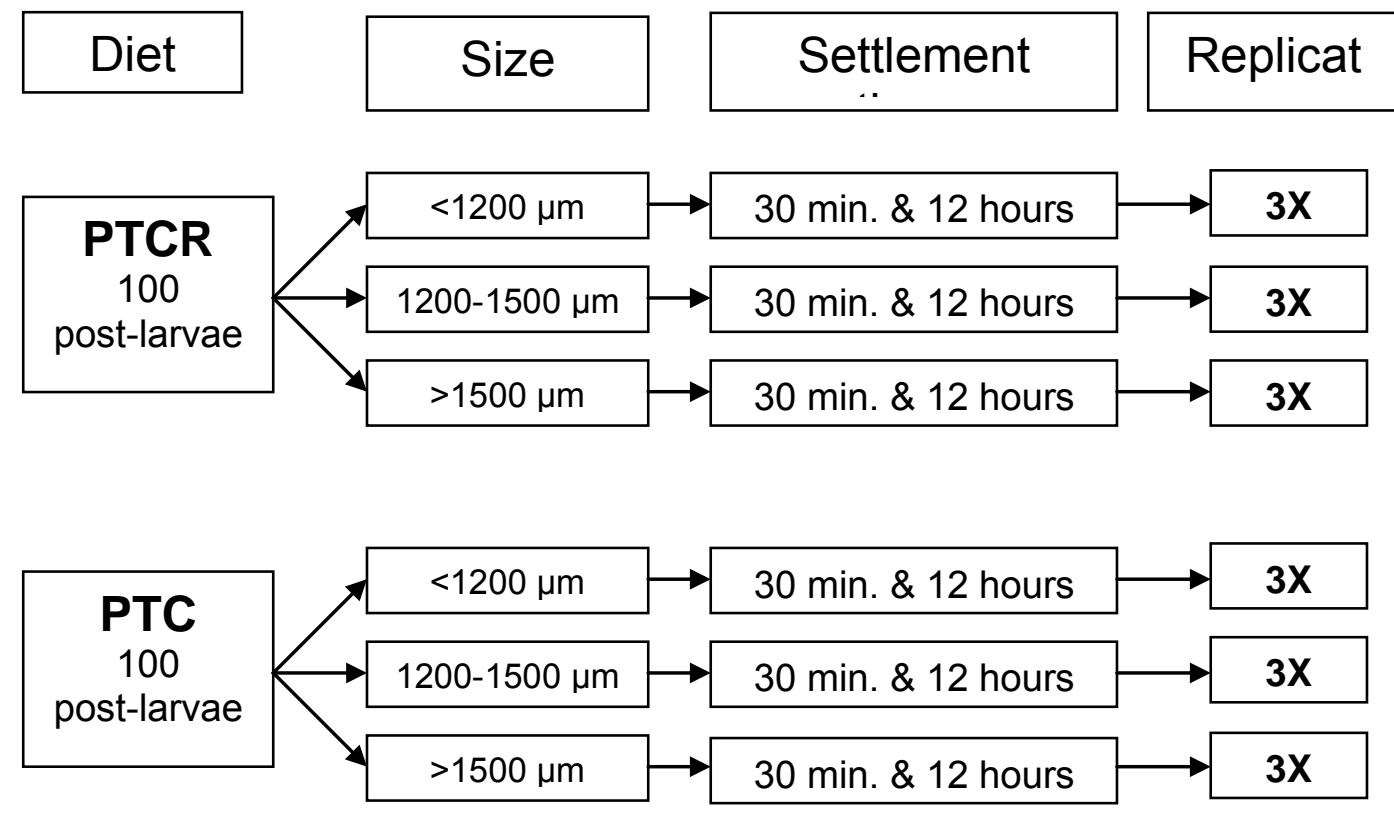

Figure 3. Pecten maximus. Percent detachment (mean $\pm S D, n=3$ ) of post-larvae $(>1500 \mu \mathrm{m})$ fed PTC in benthic biological flumes (mean \pm SD) as a function of hydrodynamic flows (rapid, rapid-gradual and gradual). See text for diet descriptions.

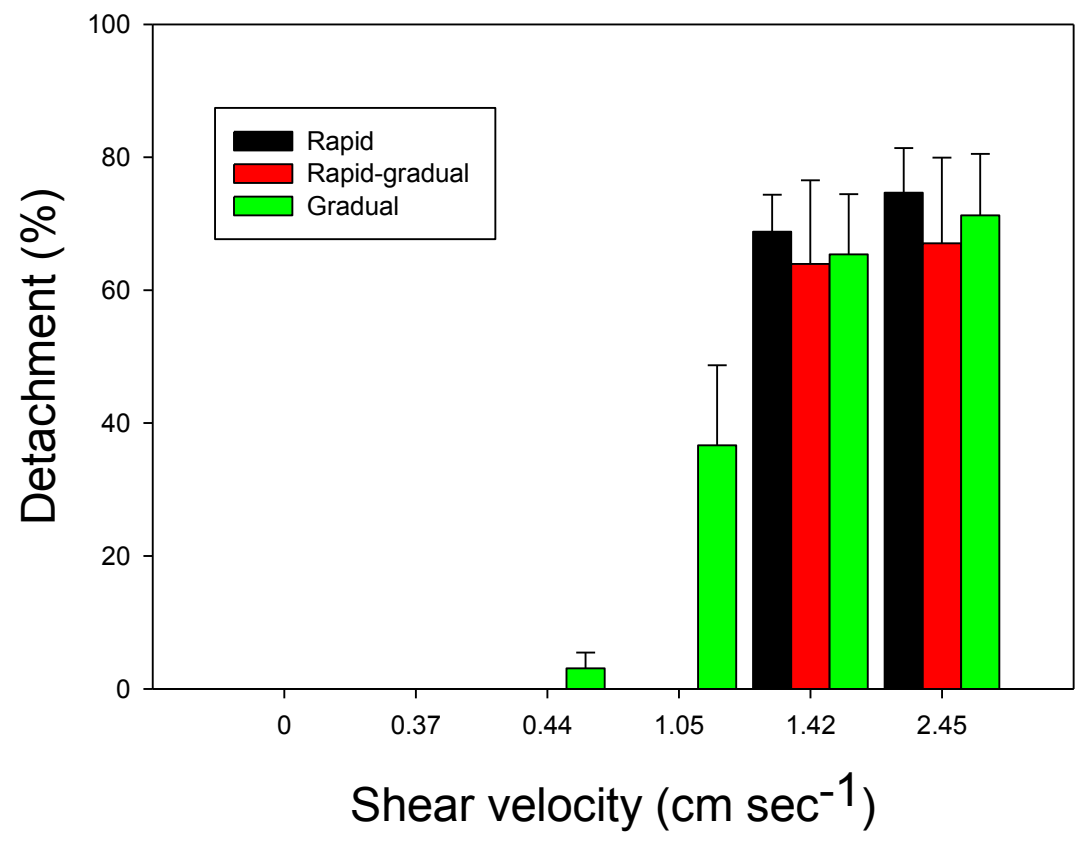


Figure 4. Pecten maximus. Percent detachment (mean $\pm S D, n=3)$ ) in benthic biological flumes of post-larvae fed PTC or PTCR as a function of shear velocity, attachment period (12 h; $30 \mathrm{~min}$.) and size of post-larvae $(<1200 \mu \mathrm{m}, 1200-1500 \mu \mathrm{m},>1500 \mu \mathrm{m})$. See text for diet descriptions.

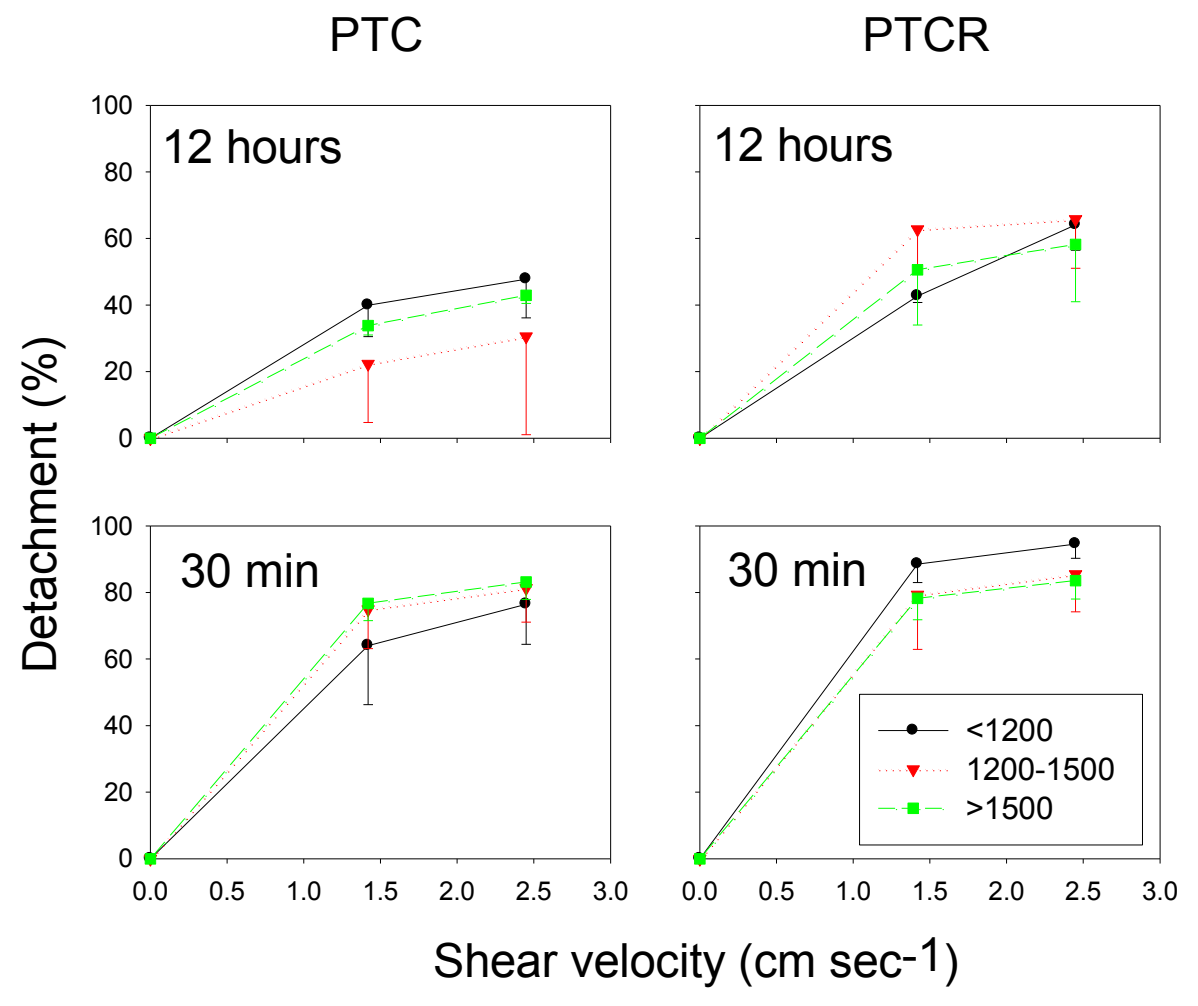

